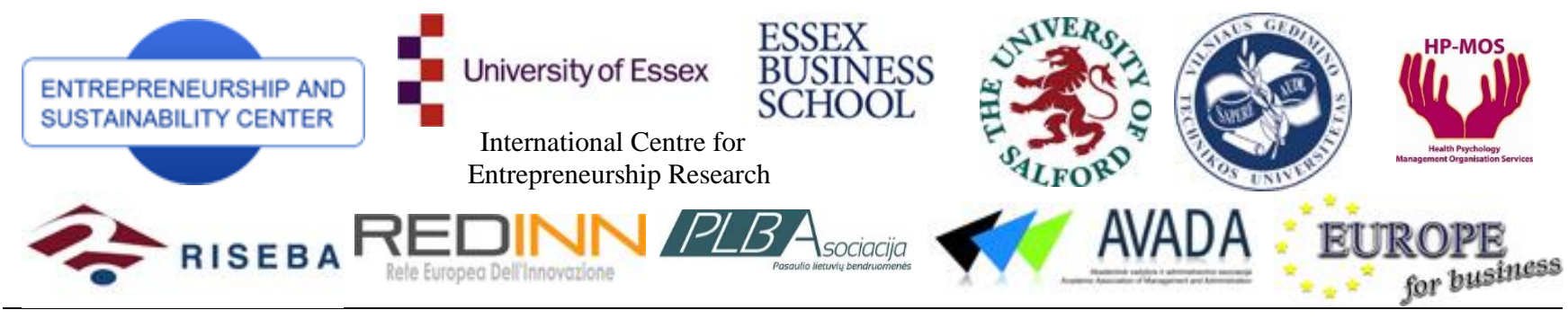

ENTREPRENEURSHIP AND SUSTAINABILITY ISSUES

ISSN 2345-0282 (online) http://jssidoi.org/jesi/

\title{
ENTREPRENEURSHIP AND ENERGY CONSUMPTION PATTERNS: CASE OF HOSEHOLDS IN SELECTED COUNTRIES ${ }^{1}$
}

\author{
Manuela Tvaronavičienė \\ Vilnius Gediminas Technical University, \\ Sauletekio Av. 11, Vilnius LT-10223, Lithuania \\ E-mail: manuela.tvaronaviciene@vgtu.lt
}

Received 20 March 2016; accepted 16 July 2016

\begin{abstract}
Entrepreneurship is about pooling not necessarily available resources for implementation activities, which are to be characterized by competitive advantage over other ones. The following question is being raised: how entrepreneurial behavior in energy usage area affects competitive advantage of companies' developing activities in different countries. There is almost unanimous agreement, that energy saving behavior is considered as important irrespective of country, in which a business is located. We question this assumption, and seek to find out how much attitudes differ, and if they depend on level of countries' development. It is supposed that entrepreneurial behavior styles are closely related to households' habits. Hence, in order to answer the question raised household energy usage patterns in selected countries will be tackled and compared, consistent patterns identified. The results found would contribute to research of entrepreneurship styles and their impact on long-rage competitiveness of business companies.
\end{abstract}

Keywords: entrepreneurship, energy intensity, households, long-rage forcasting

Reference to this paper should be made as follows: Tvaronavičienė. 2016. Entrepreneurship and energy consumption patterns: case of hoseholds in selected countries Entrepreneurship and Sustainability Issues 4(1): 74-82.

DOI: http://dx.doi.org/10.9770/jesi.2016.4.1(7)

\footnotetext{
${ }^{1}$ This research was supported by the project, which has received funding from the European Union's Horizon 2020 research and innovation programme under the Marie Skłodowska-Curie grant agreement No 645730.
}

The article reflects the views only of the authors, and the Commission cannot be held responsible for any use which may be made of the information contained therein. The information in this document is provided as is and no guarantee or warranty is given that the information is fit for any particular purpose. The user thereof uses the information at its sole risk and liability. 


\section{The International Journal \\ ENTREPRENEURSHIP AND SUSTAINABILITY ISSUES}

ISSN 2345-0282 (online) http://jssidoi.org/jesi/

2016 Volume 4 Number 1 (September)

JEL Classifications: N70, D1, O1

\section{Introduction}

Basing on the scientific literature authors (Cherp, Jewell 2014) draw attention into different periods, characterized by different contexts of energy security perception. One, early period, dates back to age of oil prices in 1970s. 2000s are indicated as another period, which is characterized by issues of different origin. Increasing demand of oil in Asia, Europe's dependency on gas and environmental degradation due to increase in energy use become problems under consideration. Hence energy availability represents the classical, or early characteristics of energy security, while affordability and acceptability may be conditionally called "new" characteristics, which are introduced in attempt to address contemporary issues of global development, such as increasing demand of energy, triggered by increasing population and respective increase of economic activities, and consequent environmental degradation (Tvaronavičienė 2012; Antanavičienė 2014; Balitskiy et al. 2014; Balkytė, Tvaronavičienė 2010; Bilevičienė, Bilevičiūtė 2015; Caurkubule, Rubanovskis 2014; Corneliu, Tamošiūnienè 2015; Dezellus et al. 2015; Lapinskienẻ et.al. 2014; Peker et al. 2014; Rakauskienè 2014; Vosylius et al. 2013; Tvaronavičienè 2014; Tvaronavičienè et al. 2014; (Raudeliūniené et al. 2014; Jefremov, Rubanovskis 2015; Vasiliūnaitė 2014; Lapinskienè et al. 2013; Bistrova et al. 2014).

The complexity of energy security conceptualization due to its close relation to security, economic growth and sustainable development issues caused intensive discussions about energy security dimensions, which are reflected in ample sources e.g. (Vosylius et al. 2013; Tvaronavičienė 2014; Tvaronavičius, Tvaronavičienė 2015: Scaringelli 2014). The way how researchers, politicians and other stakeholders introduce new dimensions is vividly described in recent paper titled "Three blind men and an elephant: The case of energy indices to measure energy security and energy sustainability (Narula, Reddy 2015): „The paper compares three different indices 'Energy Sustainability Index', 'International Index of Energy Security Risk' and 'Energy Architecture Performance Index' along with their variants to examine if they provide consistent results for various countries. A comparative assessment reveals that the three indices provide different country rankings, which are inconsistent. This situation is akin to three blind men groping the elephant with each one measuring a different part of the body and asserting that only their assessment is true"(Narula, Reddy 2015). Here we need to note, that energy security facets have to be discussed further, in order they could be measured and controlled. We suggest that indicators energy efficiency in various sectors have to be discussed and highlighted as being considerably important to be monitored. Energy efficiency depends of approaches and behavioural patterns. Hence we believe that energy efficiency and energy use patterns are the most vividly reflected by household sector. Therefore in this paper we tackle household sector energy intensities in differently developed European countries.

Before we go to this analysis, let us take a glance at variety of energy security facets, suggested by other authors. In Table 1 we provide example of main aspects of another approach to energy security. We believe that all those facets, mentioned by various authors should be ultimately taken into account.

We think that additional dimensions should be added: behavioral practices, leadership, education, absorptive capacity (like in technology transfer), sustainable law, safety of society, literacy, awareness (Dudzevičiūtè et al. 2015; Njaramba et al. 2015; Tvaronavičienè et al. 2015).

Approach top-down should be combined with bottom-up. As survey shows, exporting companies do not care much about long term prospective. Users have to share responsibility by sharing responsibility for energy security. Hence, indexes one or another have to incorporate human behavior constituent. Here it is needed to point out, that energy security issues embraces many sciences, economics, management, engineering, and even sociology. Efficiency of energy use, which is reflected by energy intensity indicator, is affected by multiple factors, which in their turn can be 


\section{The International Journal \\ ENTREPRENEURSHIP AND SUSTAINABILITY ISSUES}

ISSN 2345-0282 (online) http://jssidoi.org/jesi/

2016 Volume 4 Number 1 (September)

elaborated by within framework of all disciplines listed above. Further we will turn to our analytical part, which is done by employing econometric tools and comparative analysis, and is attributed to research area of economics.

\section{Forecast and comparative analysis of final energy intensities of households in selected countries}

Sections should not be numbered. In general, after the abstract the background and the purpose of the study should be stated first in the introduction, followed by sections in which details of the methods, materials, procedures, and equipment used should be described. Discussion and conclusions should follow. The reference list must be provided at the end of the document. Appendices may be employed if appropriate.

\subsection{Research methodology}

Energy intensity of final energy consumption considerably depends on demand, which stems from activity of households, mainly in the area of heating and cooling, and activities of agriculture, industry, services and mode of transportation. In order to manage demand, we need to estimate, forecast and benchmark energy intensity in listed above areas. Since households' activity affects all areas of life, we will tackle households' final energy consumption in differently developed countries.

If we managed to benchmark correctly energy intensity for households we could ultimately finish with more favorable energy balance. We are assuming that forecasted in long-term energy intensity in developed countries would allow us to set target for less developed countries. This assumption is based on economic law of universal converging. Besides we assume that energy efficiency would gradually increase, and respectively energy intensity would diminish due to technological progress and energy stewardship behavior (Tvaronavičiené 2012; Dudzevičiūtė et al.2015; Tvaronavičienė et al.2015; Laužikas et al.2015, Grubicka, Matuska 2015; Ala-Juusela et al.2014; Dzemyda, Raudeliūnienè, 2014; Dobele et al.2015; Olaniyi; Reidolf 2015; Oganisjana, Surikova, S. 2015; Tvaronavičienè, Černevičiūtė 2015; Leonavičius et al.2015; Baublys et al.2015; Ignatavičius et al.2015).

For forecasting of energy intensities we will use rather unique modelling tool: The Long-range Energy Alternatives Planning system (LEAP) is a widely-used software tool for energy policy analysis and climate change mitigation assessment developed at the Stockholm Environment Institute (SEI). It has been adopted by thousands of organizations in more than 190 countries worldwide. Its users include government agencies, academics, nongovernmental organizations, consulting companies, and energy utilities, and it has been used at scales ranging from cities and states to national, regional and global applications. (LEAP web site: www.energycommunity.org).

We will use LEAP software for long-range forecasting purposes, despite this tool provides much possibilities, which reach much farer than the forecasting, such as modelling of activity levels and energy intensities under different conditions, such as GDP growth, changed structures of economies of selected countries, energy mix and etc. Here we assume, that modelling is relevant and reasonable only after forecasting of selected indicators is performed and comparative analysis of obtained results is being done and economically interpreted. The tool selected for analysis provides possibilities to forecast using real data or to choose scenario (e.g. mitigation), which assumes conditions in the future would change. Again, we claim that it is reasonable to elaborate scenarios, other than ceteris paribus only after energy intensities under unchanged conditions are being juxtaposed and tendencies of such in a long-run revealed.

Let us stop on time frame of forecasting. Usually we distinguish the following time perspectives used for forecasting: short-term (one year), medium (up to five years); mezzo (up to 10 -15 years) and long term (up to 50 years). Actually, time periods, longer than 15 years are already considered as being long-term. In our case, we will be tackling results of forecasting, embracing year 2050; it means we will deal with extremely long period, what would ultimately allow to purify tendencies, which, actually, are set by historical and current economic data. Here it is important to note, that the modelling tool, we are going to employ does not require data input, but operates on data, which are already extract from relevant databases and reach back to year 1990. 


\subsection{Research limitation}

In our forecasting we will rely on baseline scenario, what means, that we assume, that current conditions would be valid for all years up 2050. Of course, in reality conditions might change, but adopting ceteris paribus assumption is valuable from the following point of view: we are getting results, which would occur if there no cardinal changes in approaches towards energy consumption take place. Therefore need for changes can be estimated.

\section{Analysis and results}

The following countries have been selected for energy intensity analysis: Lithuania, Estonia, Bulgaria, Belgium, Germany and Luxemburg. Selection of those countries has been made basing on provided arguments. Lithuania and Estonia are similar countries in terms of geographical location, history and level of economic development. Bulgaria has been selected as country, which is among the weakest among European Union members judging from the point of view of statistically measured economic development. Belgium, Germany and Luxemburg represent the richest the EU countries. Those three countries has been selected with a purpose to observe if consistent patterns can be traced; i.e. to verify, if forecasted energy intensities can be characterized by the same trends of change, and if countries' size and economic specialization affect trends, which will be revealed in result of analysis At first let us clarify how much selected countries differ by energy consumption level at the current moment. For the current moment we will take forecasted energy intensity in household sector for year 2017. Differences we will reflect graphically (Fig.1).

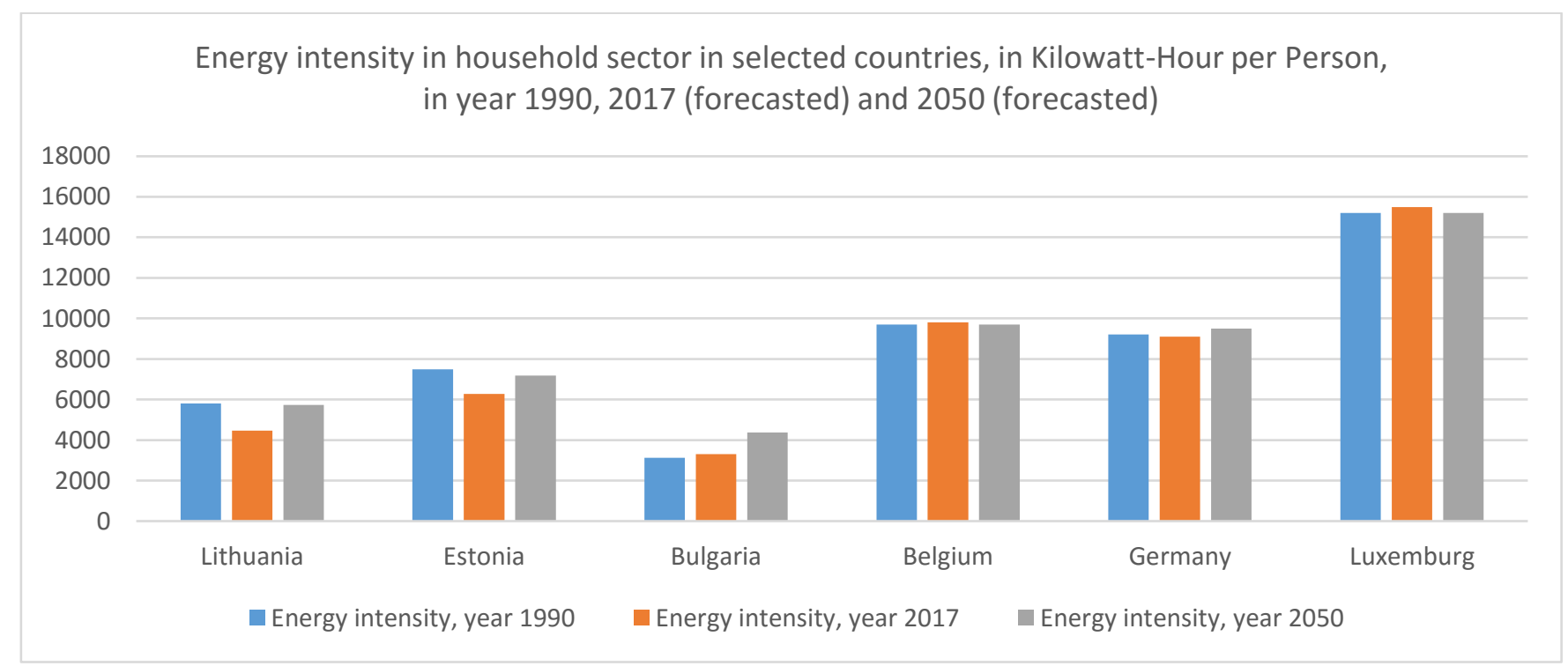

Fig. 1. Distribution of forecasted energy intensities in household sector, year 2017 (in Kilowatt-hour per Person)

Hence, in Figure 1 range of forecasted energy intensities in household sector is presented for year 2017. It is obvious that selected countries could be characterzed like considerably differing in energy use in household sector. What is peculiar about the energy intensities, that more developed countries appear to much more intensive in household sector. Meanwhile, according assumption raised, better developed countries have to be less energy intensive due to the newest energy saving technologies used and state policies orientated to energy stewardship. 


\section{ENTREPRENEURSHIP AND SUSTAINABILITY ISSUES}

ISSN 2345-0282 (online) http://jssidoi.org/jesi/ 2016 Volume 4 Number 1 (September)

Here, data witness that less developed countries are less energy intensive; their consumption patterns affect energy security state less if to compare to highly developed countries. Another moment, which needs to be emphasized is range of difference observed: it appears that such country as Lithuania is almost three times less energy intensive in household sector if to compare to e.g. Luxemburg. In Table 2 forecasted energy intensities for selected countries are presented. We have possibility to observe tendencies of energy intensities change and to make conclusions about behavioral patterns of households in energy use. Despite significant decrease of energy intensities, especially in highly developed countries, is expected, forecasted data does not allow to verify such expectation. It appears that energy intensities in Belgium, Germany and Luxemburg remain high, and diminishing tendency does not exist. The tendencies of energy consumption could not be positively evaluated, since they tend to enhance energy insecurity, and are detrimental to secure sustainable development aim (Table 2, Fig. 2).

Table 2. Energy intensities in analyzed countries, in Kilowatt-hour per Person, in year 1990 year 2017(forecasted) and year 2050(forecasted) (Source: author)

\begin{tabular}{l|l|l|l}
\hline Countries & Energy intensity, year 1990 & $\begin{array}{l}\text { Energy intensity, year } \\
2017\end{array}$ & Energy intensity, year 2050 \\
\hline Lithuania & 5796 & 4461 & 5730 \\
\hline Estonia & 7489 & 6283 & 7184 \\
\hline Bulgaria & 3115 & 3313 & 4375 \\
\hline Belgium & 9700 & 9800 & 9700 \\
\hline Germany & 9200 & 9100 & 9500 \\
\hline Luxemburg & 15200 & 15500 & 15200 \\
\hline
\end{tabular}




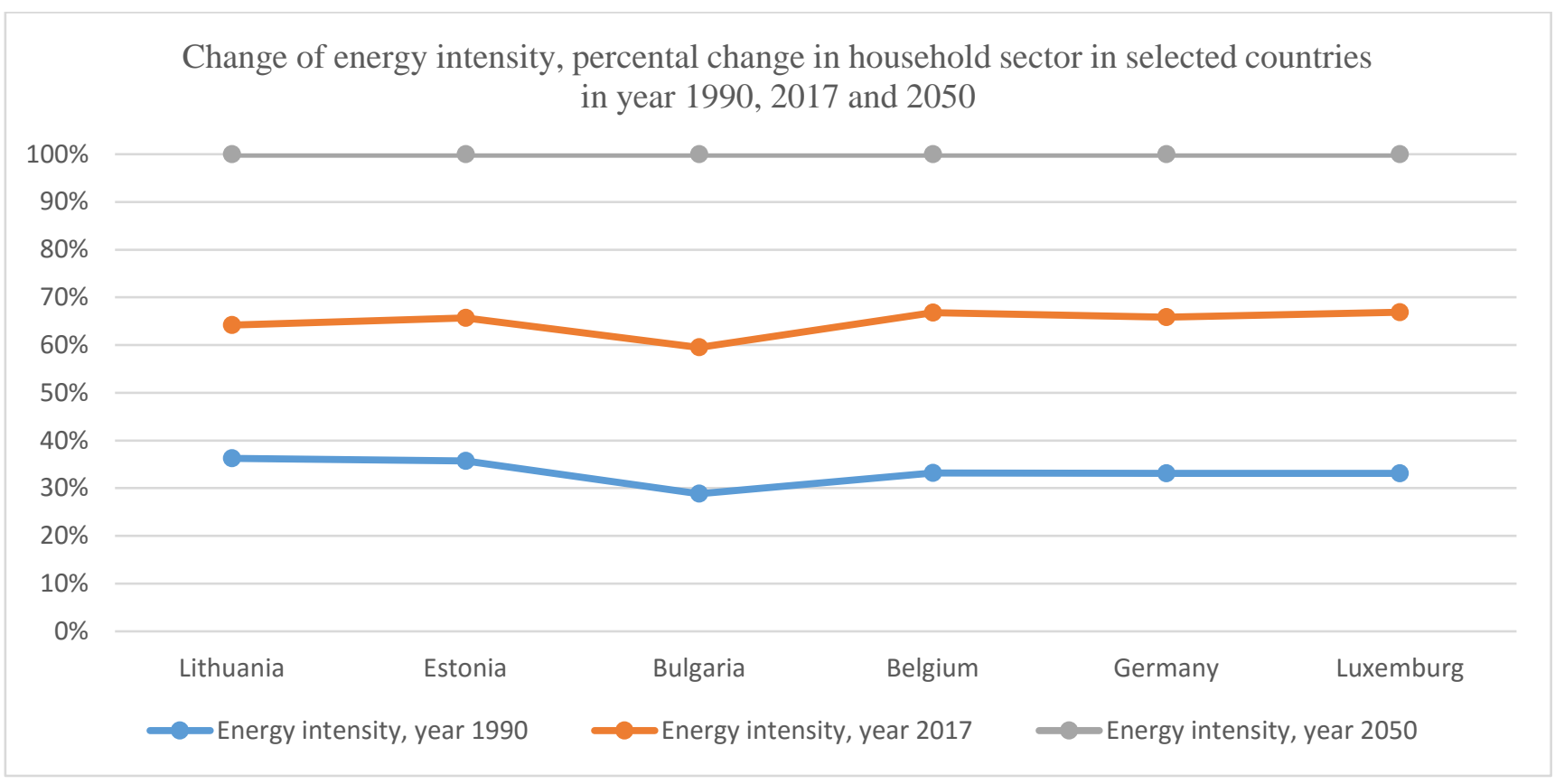

Fig. 2. Change of energy intensity, percental change in household sector in selected countries in year 1990, 2017 and 2050

Energy intensities in currently less developed countries doe not increase, except of Bulgaria. In Lithuania and Estonia energy intensities diminish slightly.The obtained results signal about inefficiency of policies oriented to energy stewardship, especially in developed countries, which obviously are used to excessive counsumption brought by favourable economic development decades.

\section{Conclusions}

The presented paper argues, that energy security has to be perceived as constituent of security of countries and individuals. Security in its own turn serves as one of preconditions of sustainable development. Long-term secure sustainable development could be achieved only by involving individuals and organizations into process of energy stewardship and so gradually shifting self-perception from energy security observers to energy security enhancers. Basing on the performed analysis the following insights can be formulated.

The first, energy intensity of households in the long run is not going to diminish. That tendency has to be taken into account and interpreted as conditional threat, which can undermine energy security in the future.

The second, proactive policy in energy consumption area is urgent, otherwise energy stewardship culture is difficult to implement.

The third, we suggest strengthen benchmarking attempts. Energy intensity in household sector could be benchmarked by considerably lower intensity than demonstrates highly developed European countries. Revealed trends and concrete results can be followed by respective policy implications in the area of energy use.

Here we need to point out, that evaluation of energy use in household sector is of majour importance of at least two reasons: (1) households consume the largest share of energetic resourses if to compare it to share of industry, services, agriculture and transport; (2) behavioral patterns of households are naturally trnasfered to business sector, i.e. to working environment of the same people or households. Therefor it is difficult to overestimate significance 


\section{ENTREPRENEURSHIP AND SUSTAINABILITY ISSUES \\ The International Journal}

ISSN 2345-0282 (online) http://jssidoi.org/jesi/ 2016 Volume 4 Number 1 (September)

of measurement, management and control of households' behavior in energy consumption area, which partly determine long-term competitiveness of entrepreneurial ventures, industries, and, ultimately, countries.

\section{Acknowledgements}

The research leading to these results has received funding from the European Community's Seventh Framework Programme (FP7/20072013). The article reflects the views only of the authors, and the Commission cannot be held responsible for any use which may be made of the information contained therein. The information in this document is provided as is and no guarantee or warranty is given that the information is fit for any particular purpose. The user thereof uses the information at its sole risk and liability

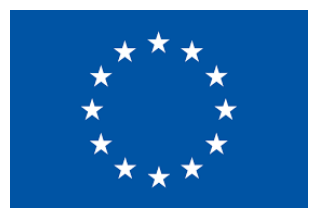

\section{References}

Ala-Juusela, M.; Short, M.; Shvadron, U. 2014. Tools to support sustainable entrepreneurship in energy positive neighbourhoods, Entrepreneurship and Sustainability Issues 2(2): 49-59.

Antanavičienė, J. 2014. Foreign direct investment: driving factors and outcomes for secure and sustainable development, Journal of Security and Sustainability Issues 3(3): 55- 67.

Balitskiy, S., Bilan, Y.; Strielkowski, W. 2014. Energy security and economic growth in the European Union, Journal of Security and Sustainability Issues 4(2): 123-130.

Balkyte, A.; Tvaronavičiene, M. 2010. Perception of competitiveness in the context of sustainable development: facets of "sustainable competitiveness, Journal of Business Economics and Management 11(2): 341-365.

Baublys, J.; Miškinis, V.; Konstantinavičiūtè, I.; Lekavičius, V. 2015. Energy efficiency as precondition of energy security, Journal of Security and Sustainability Issues 4(3): 197-208.

Bilevičienè, T.; Bilevičiūtè, E. 2015. Influence of employment on strategy of sustainable development implementation, Journal of Security and Sustainability Issues 4(3): 520-535.

Bistrova, J.; Lace, N.; Tvaronavičienė, M. 2014. Corporate governance as a crucial factor in achieving sustainable corporate performance, Journal of systemics, cybernetics and informatics 12(3): 82-90

Caurkubule, Ž.; Rubanovskis, A. 2014. Shadow economy as an obstacle to sustainable economic development, Journal of Security and Sustainability Issues 4(2): 175-186.

Cherp, A.; Jewell, J. 2014. The concept of energy security: Beyond the four As, Energy Policy 75: 415-421.

Corneliu, M.; Tamošiūnienè, R. 2015. Modern approaches in quantifying economic security. case sudy of Estonia, Latvia, Lithuania and Republic of Moldova, Journal of Security and Sustainability Issues 4(4): 596-610.

Dezellus, E.; Ferreira, L.; Pereira, N.; Vasiliūnaitè, R. 2015. Entrepreneurship conditions: energy resources' Prices and energy consumprion peculiarities in developed countries, Entrepreneurship and Sustainability Issues 2(3):163-170.

Dobele, L.; Grinberga-Zalite, G.; Kelle, L. 2015. Sustainable economic development: scenarios for promotion of social innovation in Latvia, Journal of Security and Sustainability Issues 5(2): 149-158. 


\section{ENTREPRENEURSHIP AND SUSTAINABILITY ISSUES}

ISSN 2345-0282 (online) http://jssidoi.org/jesi/ 2016 Volume 4 Number 1 (September)

Dudzevičiūtė, G.; Mačiulis, A.; Tvaronavičienė, M. 2014. Structural changes of economies: Lithuania in the global context, Technological and economic development of economy 20(2): 353-370.

Dzemyda, I.; Raudeliūnienė, J. 2014. Sustainable youth entrepreneurship in conditions of global economy toward energy security, Entrepreneurship and Sustainability Issues 1(4): 247-256.

Grubicka, J.; Matuska, E. 2015. Sustainable entrepreneurship in conditions of UN (Safety) and technological convergence, Entrepreneurship and Sustainability Issues 2(4):188-197.

Ignatavičius, R.; Tvaronavičienė, M.; Piccinetti, L. 2015. Sustainable development through technology transfer networks: case of Lithuania, Journal of Security and Sustainability Issues 4(3): 261-267.

Jefremov, V.; Rubanovskis, A. 2015. Towards a sustainable Latvian energy resources and energy markets in the context of the EU, Journal of Security and Sustainability Issues 4(3):552-563

Lapinskienè, G., Tvaronavičienè, M.; Vaitkus, P. 2014. Greenhouse gases emissions and economic growth - evidence substantiating the presence of environmental Kuznets curve in the EU, Technological and Economic Development of Economy 20(1): 65-78.

Lapinskienė, G.; Tvaronavičienè, M.; Vaitkus, P.. 2013. The analysis of the validity of environmental Kuznets Curve for the Baltic States, Environmental and Climate Technologies 12: 41-46.

Laužikas, M.; Tindale. H.;Tranavičius, L.; Kičiatovas, E. 2015. Effects of consumer behaviour on innovations in fast food industry, Entrepreneurship and Sustainability Issues 3(1):85-104.

Leonavičius, V.; Genys, D.; Krikštolaitis, R. 2015. Public perception of energy security in Lithuania, Journal of Security and Sustainability Issues 4(4): 311-322.

Månsson, A., Johansson, B.; Nilsson, L.J., 2014. Assessing energy security: An overview of commonly used methodologies, Energy 73: $1-14$.

Njaramba, J.; Chigeza, P.; Whitehouse, H. 2015. Financial literacy:the case of migrant African-Australian women entrepreneurs in the cairns region, Entrepreneurship and Sustainability Issues 3(2):198-208.

Oganisjana, K.; Surikova, S. 2015. Social innovation in the promotion of sustainable development of the contemporary Latvian society, Journal of Security and Sustainability Issues 5(2): 249-258.

Olaniyi E. O; Reidolf, M. 2015. Organisational innovation strategies in the context of smart specialization, Journal of Security and Sustainability Issues 5(2): 213-227.

Narula, K.; Reddy, B.S. 2015. Three blind men and an elephant: The case of energy indices to measure energy security and energy sustainability, Energy 80: 148-158.

Peker, S., Tvaronavičienė, M.; Aktan, B. 2014. Sustainable risk management: fuzzy approach to volatility and application on FTSE 100 Index. Entrepreneurship and Sustainability Issues 2(1): 30-36.

Rakauskienè, O.G. 2014. Long term changes in the quality of life of Lithuanian population: 20 years in the market economy, Journal of Security and Sustainability Issues 4(1): 41-58.

Raudeliūnienè, J.; Tvaronavičienė, M.; Dzemyda, I.; Sepehri, M. 2014. Sustainable entrepreneurship through energy stewardship: role of values and behavioral patterns, Entrepreneurship and Sustainability Issues 2(2): 107-117

Scaringelli, M.A. 2014. Are the foreign controlled firms more environmentally sustainable than domestically controlled ones? Journal of Security and Sustainability Issues, 4(2): pp.131-146.

Travkina, I.; Tvaronavičienė, M. 2015. Peculiarities of export structure in lithuania: synthesis and analysis, Entrepreneurship and Sustainability Issues 2(4): 233-247. 


\section{ENTREPRENEURSHIP AND SUSTA International Journal \\ ISSN 2345-0282 (online) http://jssidoi.org/jesi/ \\ 2016 Volume 4 Number 1 (September)}

Tvaronavičienè, M. 2012. Contemporary perceptions of energy security: policy implications, Journal of Security and Sustainability Issues 1(4): 235-247.

Tvaronavičiene, M. 2014. If industrial sector development is sustainable: Lithuania compared to the EU, Entrepreneurship and Sustainability Issues 1(3): 134-142.

Tvaronavičienė, M.; Černevičiūtè, J. 2015. Technology transfer phenomenon and its impact on sustainable development, Journal of Security and Sustainability Issues 5(1): 87-97

Tvaronavičienè, M.; Mačiulis, A.; Lankauskienè, T.; Raudeliūnienė, J.; Dzemyda, I.. 2015. Energy security and sustainable competitiveness of industry development, Economic Research-Ekonomska Istraživanja 28(1): 502-516.

Tvaronavičienè, M., Šimelytė, A.; Lace, N. 2014. Sustainable development facets: exporting industrial sectors from inside, Journal of Security and Sustainability Issues 3(4): 37-44.

Tvaronavičius, V.; Tvaronavičiene, M. 2008. Role of fixed investments in economic growth of country: Lithuania in European context. Journal of Business Economics and Management 9(1): 57-64.

Vasiliūnaite, R. 2014. Sustainable development: methodological approaches toward issues, Journal of Security and Sustainability Issues 3(3): 69-75.

Vosylius, E., Rakutis, V.; Tvaronavičienė, M., 2013. Economic growth, sustainable development and energy security interrelations, Journal of Security and Sustainability Issues 2(3): 5-14.

Manuela TVARONAVIČIENĖ is dr, professor at Vilnius Gediminas Technical University and The General Jonas Žemaitis Military Academy of Lithuania. Here research interests are: sustainable development, innovations, investments, entrepreneurship. She raised qualifications in USA, Canada, and Europe in various institutions, including such as IESE Business School of Navarra University, Harvard Business School of Harvard University, and Judge College of Cambridge University.

ORCID ID: orcid.org/0000-0002-9667-3730; RESEARCHER ID: M-2103-2016

Copyright (C) 2016 by author(s) and VsI Entrepreneurship and Sustainability Center This work is licensed under the Creative Commons Attribution International License (CC BY). http://creativecommons.org/licenses/by/4.0/

(c) (7) Open Access 